\title{
Technology advancements in antibody purification [Corrigendum]
}

\author{
Murphy C, Devine T, O'Kennedy R. Antibody Technology
}

Journal. 2016;6:17-32.

In Table 1, line 5, under Protein-A this should be 'IgM and some species IgE (human; very weak or none)'.

Also in Table 1, line 5 under Protein G, 'Human IgE, D and E' should be deleted. open access journal that provides a unique forum for articles on: point-of-care, health care diagnostics and treatment, bioengineering, biotechnology, biosensing, electronics, clinical/medical science, chemical engineering, materials science, regenerative medicine, micro-

nano-technologies, and methods and applications for nanoscience and nanotechnology. The manuscript management system is completely online and includes a very quick and fair peer review system, which is all easy to use. Visit http://www.dovepress.com/testimonials.php to read real quotes from published authors.

Submit your manuscript here: https:/www.dovepress.com/advanced-health-care-technologies-journal

submit your manuscrip

Dovepress

http:
Advanced Health Care Technologies 2017:3 I

(c) (i) (5) 2017 Murphy et al. This work is published and licensed by Dove Medical Press Limited. The full terms of this license are available at https://www.dovepress.com/terms. you hereby accept the Terms. Non-commercial uses of the work are permitted without any further permission from Dove Medical Press Limited, provided the work is properly attributed. For permission for commercial use of this work, please see paragraphs 4.2 and 5 of our Terms (https://www.dovepress.com/terms.php) 